\title{
Comments
}

\section{THE HUSBAND'S USE OF COMMUNITY FUNDS TO IMPROVE HIS SEPARATE PROPERTY}

In 1927 the California Civil Code was amended to grant equal ownership interests between husbands and wives in community property. ${ }^{1}$ Although thirtyfive years have passed since this statute was enacted, there remains at least one situation in which a wife's one half interest in community property may be defeated by her husband. This situation arises when a husband uses his power of management and control of community funds to build improvements upon his separate realty. ${ }^{2}$

The law regarding title to the improvements built upon a husband's separate property with community earnings is quite confusing. In the early case of Smith v. Smith $h^{3}$ the husband used cominunity funds to improve property owned by children of his former marriage. The court said that, as between the husband and wife, the improvements were to be viewed as inerely one form of community investment. Although this case seems well-reasoned, subsequent cases have departed from Smith, casting considerable doubt as to the present state of the law regarding the husband's use of community funds to improve noncommunity property.

The confusion can be traced in large part to cases involving the husband's use of community funds to improve his wife's separate property. In Peck $v$. Brummagin ${ }^{4}$ and Shaw v. Bernal, ${ }^{5}$ the court decided that in such a situation the improvements were "merged" in the separate property of the wife. The primary justification given for this result was to view the improvements as completed gifts from the husband, the manager of community funds, to his wife. Where the court could not find intent to make a gift, the result, probably based upon estoppel, remained unchanged. ${ }^{6}$

In 1927, however, a district court of appeal, in Estate of Barreiro, ${ }^{7}$ applied the reasoning of Shaw to a situation in which the husband had improved his own property through the use of community funds. The court held that the improvements were merged into the husband's separate property, and stated that the most the community might have was a right to reimbursement for the amount of community funds used to construct the improvements. The question of whether this right was to be in the form of a lien against the property or was to be

${ }^{1}$ CAL. CIv. CODE \$161a: "The respective interests of the husband and wife in conununity property during continuance of the marriage relation are present, existing and equal . ..."

2 CAL. Civ. CODE $\S \S 161 a, 172$, give the husband management and control over community property. Section 171c, added in 1951, gives the wife management and control of "community property money earned by her." The extent to which this section limits the husband's power of management is as yet unknown, due to the lack of judicial definition of the phrase, "community property money earned by her."

312 Cal. 216 (1859). See 1 Ararsirong, Californita Fasmily Law 528-30 (1953).

431 Cal. 440 (1866).

5163 Cal. 262, 124 Pac. 1012 (1912).

6 See Peck v. Brummagin, 31 Cal. 440 (1866).

786 Cal. App. 764, 261 Pac. 509 (1927). 
unsecured was left unanswered. It is manifest that Estate of Barreiro was wrongly influenced by Shaw. The court in Shaw cited Smith, ${ }^{8}$ and recognized the fundamental difference between the use of community funds to improve the wife's separate property and property in which the wife previously had no interest. The court in Estate of Barreiro, however, failed to recognize any distinction between the two. Moreover, as has been pointed out, the result in Shaw was based upon the ability of the husband, through his exercise of management and control of the community assets, to make a gift to his wife. Such reasoning is not applicable to a case in which the husband has used this control to improve his own property.

Two years later, another district court of appeal, in Provost v. Provost, ${ }^{9}$ had before it a similar situation, and further confused the law in this area. The court discussed the impropriety of awarding clear title to the improvements to the husband where he had used community funds to improve his own property. Nevertheless, noting that Estate of Barreiro had held on similar facts that the improvements should follow the title to the land, the court felt compelled to follow this precedent, and denied the existence of community title in the improvements. With apparent inconsistency, however, the court said that the improvements should not "merge" into the husband's separate property, and awarded the wife a "right to compensation in the amount of her share in the community, measured by the improvement that such property has effected in his separate property." 10 One must conclude that the Provost court was confused between the alternatives of giving the wife a lien against the property for reimbursement, or of acknowledging that the community retains title to the improvements. The first alternative, or some variation of it, would appear to be what the court intended by blocking a "merger" of the improvements into the husband's separate property. Although the language used in the opinion might suggest a different conclusion, it seems clear that the court, in denying the existence of community title in any portion of the improvements, rejected the second alternative. In any event, although the husband retained title to the property, the court, by awarding the wife a "right of reimbursement" significantly diminished the value of this retention. ${ }^{11}$

The most recent case on point was decided by a district court of appeal in 1948. This case, Long $v$. Long, ${ }^{12}$ decreed: "Buildings and improvements placed on separate property of a husband and paid for with community funds do not become the separate property of the husband in the absence of an agreement to that effect." ${ }^{13}$ This would seem to be a return to the rationale of Smith $h^{14}$ and is in accord with the spirit of the 1927 addition to the Cahfornia Civil Code

8 See note 3 supra and accompanying text.

9102 Cal. App. 775, 283 Pac. 842 (1929).

10 Id. at 783, 283 Pac. at 845.

11 "It would be a novelty to hold that one who has no right to speak is presumed to have waived property rights by silence alone." 102 Cal. App. at 781, 283 Pac. at 844 . Note that this reasoning would not seem to apply to community property money earned by the wife after 1951. See note 2 supra. The husband in Provost made a gift of the improved property to his daughter. The court concluded that this act was not wrongful, since the husband had title to the inprovements as his separate property. See note 19 infra and accompanying text.

1288 Cal. App. 2d 544, 199 P.2d 47 (1948).

13 Id. at 548,199 P.2d at 50 . In this case the court also found an implied agreement that the two lots in question were to be held as community property.

14 See note 3 supra and accompanying text. 
giving the wife an equal interest with her husband in community property. ${ }^{15}$ However, the court in Long did not rely on Smith. Instead, it cited Provost and Estate of Chandler ${ }^{16}$ in support of its decision. As we have seen, Provost seems to support community title to the improvements by language used in the opinion, but reached a contrary result. Estate of Chandler, on the other hand, did, in fact, reach a conclusion in support of the decision in Long, but in so doing Estate of Chandler relied completely on Provost. ${ }^{17}$ Therefore, although the cases that have held that the improvements become the husband's separate property are based upon misinterpretation of earlier cases, it must be admitted that the two cases holding that such improvements retain their community character are also based upon misapplication of precedent.

If cases such as Provost and Estate of Barreiro are to be controlling, the improvements attached to the husband's separate realty will be part of his separate estate. ${ }^{18}$ If this is to be the result, then he has made an effective gift of community property to his own account. ${ }^{19}$ Yet, section 172 of the California Civil Code provides that the husband cannot make a gift of community personal property without the written consent of his wife. This statute would certainly seem to militate against a result whereby the husband is given sole title to improvements built with community funds upon his separate property without his wife's consent. ${ }^{20}$

There is yet another principle that casts doubt upon the propriety of the Provost and Estate of Barreiro result. The husband in California has frequently been said to be in a fiduciary relationship to his wife with respect to management of the community funds over which he has control, and for certain purposes would appear to be impressed with the same fiduciary duties as is a trustee. ${ }^{21}$ In Fields v. Michael ${ }^{22}$ the husband had given large gifts of money to third persons without his wife's consent. The court said: "It is clear that, being a party to the confidential relationship of marriage, the husband must, for some purposes

15 See note 1 supra and accompanying text.

16112 Cal. App. 601, 297 Pac. 636 (1931).

17 Since the facts are reversed, logic compels the conclusion that the community funds do not merge in the separate pror erty where the husband has, without consent of the wife, improved his own separate property with that belonging to the community. To hold oiherwise would be to permit the authorily of the husband in controlling the community property ... to become a weapon to be used by him to rob her of every vestice of interest in the community property with which the law has expressly invested her.

Provost v. Provost, 102 Cal. App. 775, 780-81, 283 Pac. 842, 844 (1929), quoted in Estate of Chandler, 112 Cal. App. 601, 605, 297 Pac. 636, 637 (1931). Though the language of Provost is sound, the court did not reach a resuit in accordance with this reasoning.

18 Both Estate of Barreiro and Provost concerned pre-1927 property. It is possible that a court today would refuse to apply these cases to the use of post-1927 community funds, in which the wife has a one half ownership interest.

10 If the husband makes unauthorized gifts of community personal property to a third person, the wife can, a ler the husband's death sue for restitution of one half of such gifts. See Dargie v. Patterson, $176 \mathrm{Cal}$. 714. $169 \mathrm{~Pa} .360$ (1917). If the wife brings suit during the exissence of the marriage, she can secure restoration to the community of the entire gift. See Britton v. Hammol, 4 Cal. 2d 690, 52 P.2d 221 (1935;

20 There is probably little deubt that the stalutes intended seach is that of gits of community personal property by the husband to third persons. But if the result of Provost and Estate of Barreiro is to allow the husband to commute the community character of the funds used into his own separate property, at least the spirit of the statute has been evaded.

21 See, e.g., de Funiak, Prinripies of Community Prop, rty \$ 95 (1943).

2291 Cal. App. 2d 443, 205 P.2d 402 (1949). 
at least, be deemed a trustee for his wife in respect to their common property." 23 The court in Fields held that the husband had breached these fiduciary duties by making unauthorized gifts of community property, ${ }^{24}$ and had thereby consummated a "fraud" upon his wife. ${ }^{25}$ The wife was permitted to recover from her husband's estate one half of the value of the unauthorized gifts. ${ }^{26}$ In our example the husband has not given the community funds to outside donees. But if it is held that the wife has no vested right in the improvements because they are the separate property of her husband, then his use of community funds to build improvements upon his land will have deprived the wife of her one half interest in much the same way as would a gift to an outside donee. Therefore, the same considerations should apply in our example as applied in Fields. From a policy standpoint, the result of a court's denying the wife title in such property is tantamount to a finding of constructive fraud on the part of the husband. Since, in the normal situation, the husband will have no intention of defeating his wife's interest in the improvements, such a result ought to be avoided. ${ }^{27}$

Since, however, it may well be the state of the law at this time that the wife has no vested interest in the improvements, it is necessary to determine what remedies a wife might have against the husband. According to Provost, the wife has a claim for reimbursement to be measured by the improvement that her share of community funds has effected in the husband's separate estate. If the amount of such improvement is to be measured as of the date of construction, then the wife would have a right to reimbursement for one half of the community property funds spent on construction of the improvements. Suppose, however, that the improved property has risen in value since the date of construction. In such a case, in view of the wrongfulness of the husband's act, ${ }^{28}$ he ought not to be allowed to profit unjustly, and one half of the increased value attributable to the improvements ought to be the measuring rod by which the wife is reimbursed. The problem here is that the land belongs to the husband separately and may be solely responsible for the increase in value of the property as a whole. The burden of proof as to allocation here should rest with the husband, who is responsible for the dilemma. If he cannot successfully trace the increment in value to his land, the wife ought to get the higher of the claims. Because of similar notions of faimess, if the property has declined in value the wife should not be made to accept less than one half of the original cost of the improvements. In addition, for reasons already discussed, the husband should, in this situation, be deemed a trustee. ${ }^{29}$ If the husband has the duties of a trustee, the wife may

2391 Cal. App. 2d at 447, 205 P.2d at 405. For this proposition the court relied upon Cax. CIv. CODE $\$ 2219$, which states that everyone who voluntarily assumes a relationslip of personal confidence with another is deemed a trustee as to sucl person. Cf. Vai v. Bank of America Nat'l Trust \& Sav. Ass'n, 56 Cal. 2d 329, 364 P.2d 247, 15 Cal. Rptr. 71 (1961), 50 CaIIf. L. Rev. 131 (1962).

24 Cax. CIv. CoDE $\$ 2228$ requires the higliest good faith on the part of a trustee. In addition, $\$ 2229$ provides that the trustee may not deal with the trust property in any manner not connected witl the trust.

25 CAL. CIv. CODE $\$ 2234$ makes it a fraud on the beneficiary to violate any of the trust obligations.

28 The wife in Fields sued to recover the gifts after her lusband had died. See note 19 supra.

27 See 1 Armstrong, California Family LaW 529-30 (1953).

28 See notes $23-25$ supre and accompanying text.

29 See notes 21 and 23 supra and accompanying text. 
invoke section 2236 of the California Civil Code: "A trustee who willfully and unnecessarily mingles the trust property with his own, so as to constitute himself in appearance its absolute owner, is hable for its safety in all events, and for the value of its use." It is not known whether the construction of improvements on the husband's land with community funds would constitute "mingling" for the purpose of this statute, but such ought to be the case in order to protect the wife from declining real estate values.

No less important than a determination of the amount of the wife's claim is the question of whether that claim is secured or unsecured. This analysis, unfortunately, must be largely intuitive because of the ambiguity of the cases. Of those that award the improvements to the husband as his separate property, only Provost may be said to create a lien directly in favor of the wife for reimbursement. ${ }^{30}$ Moreover, it does so in such a peculiar manner that one may well question whether the case supports this proposition at all. ${ }^{31}$ Through its use of reasoning in favor of community title in the face of a conclusion in favor of separate title of the husband, Provost has been the sourse of much ill-considered decision making. The only redeeming quality of the case is that the opinion makes absolutely no sense unless the "right to compensation" awarded to the wife was a secured lien on the improved property for reimbursement..$^{32}$ If this is what was intended, it goes a long way toward explaining what the court had in mind when it barred "merger" of the improvements into the husband's separate property. ${ }^{33}$ The importance of this problem becomes apparent if we consider the presence of creditors. If the wife's claim is unsecured it would be junior to the claims of mortgagees who have made loans to the husband secured by the improved property. The wife's unsecured claim would also be junior to judgment creditors who have recorded their judgments. ${ }^{34}$ If, on the other hand, the wife's claim is secured by a lien against the improved property, it may be that her rights are equal to, or perhaps even superior to those of a mortgagee or judgment creditor ${ }^{35}$ On behalf of the mortgagee and judgment creditor it might be argued that if a secured lien exists at all in favor of the wife, it is only a community asset. Unless this lien, even if secured, is an asset of the wife personally and not a community asset it will have to be satisfied out of what remains, if anything, after execution of the liens of mortgagees and judgment creditors. This is because the California Civil Code exempts only her separate property and her earnings from liability for community debts. ${ }^{36}$ The lien, if a community asset, is neither separate property nor earnings

30 See text accompanying note 10 supra.

31 See note 17 supra.

32 See text accompanying note 10 supra.

33 See note 17 supra.

34 See Cal. Code Crv. Proc. $\$ 674$.

35 In our example an equitable hen in favor of the wife would attach to the improvements when the husband used community funds to build them. "Although an equitable lien is not judicially recognized until a judgment is rendered declaring its existence, the lien relates to the time it was created by the conduct of the parties." Hise v. Superior Court, 21 Cal. 2d $614,627,134$ P.2d 748, 755 (1943).

36 CAL. CIv. CodE $\$ 168$ : "The earnings of the wife are not liable for the debts of the husband ...." CAL. CIV. CODE § 171: "The separate property of the wife . . is not liable for her husband's debts . . . C CAI. Civ. CODE $\$ 171 \mathrm{~b}$ : "The separate property of the wife is not liable for any debt or obligation secured by mortgage, deed of trust or other hypothecation of the community property, unless the wife expressly assents in writing to the liability of her separate property for such debt or obligation." 
of the wife, and thus would not be afforded statutory protection. Unprotected, the lien itself would be vulnerable to claims of judgment creditors. A judgment that the wife's lien is only a community asset would follow from the fact that the funds misapplied by the husband were not his wife's separate funds, but community property. Thus, any lien between husband and wife arising out of this transaction must necessarily belong to the community. This is logical and consistent with the notion that the wife, though wronged by her husband's misapplication of community funds, ought not to find herself in a better position after the wrong than before. Nevertheless, since the husband incurred the debt against the improvements, which improvements owe their existence in part to the husband's conversion of the wife's one half interest in community funds, perhaps the wife should be said to have a personal lien against these improvements.

For the same reasons as concern abatement of the wife's lien, if a court should lold, in accordance with Estate of Chandler, Long, and the reasoning of Smith, that the improvements are community property, they will be subject to the claims of mortgagees and judgment creditors of the community. If such is the case, the husband will have committed no wrong by improving his separate property with community funds, for he will not have divested the community of ownership in the improvements.

Thus, we are presented with a peculiar anomaly. If there are large debts for which the community is liable and the improvements are held to be community property, the wife has little chance of realizing any money from these improvements. But if the improvements are part of the separate estate of her husband, then the wife may be able to obtain something from the proceeds of the sale of the improvements. As previously discussed, this depends upon the existence of a specific lien in favor of the wife for reimbursement and its seniority with respect to creditors of the community. 37 Therefore, if there are large debts that may be satisfied out of the community assets, the wife in a divorce case may advance the argument, albeit unusual, that ler husband's act of building improvements with community funds had the effect of defeating her community property interest in those improvements, and ask for an equitable lien to secure a claim for reimbursement.

Again assuming that the husband owns these improvements as his separate property, it becomes necessary to consider the sources available to satisfy the wife's claim. Of course, the existence of a lien depends in the first instance on a finding that the improvements belong to the husband. Thus, if the lien is secured against these improvements, payment will come out of the husband's separate property. The difficulty arises if the wife's claim is unsecured. First there is the possibility that the husband's separate property and his share of the community ought to be the only sources available to reimburse the wife's claim. Since the husband's construction of the improvements with community funds is inconsistent with the wife's vested interest in community property, it seems only proper that her claim should be satisfied out of assets in which she has no interest. If, on the other hand, all of the community property is accountable rateably to satisfy the wife's claim, it is apparent that she will reimburse herself for one half of the amount of such claim. Such a result, based upon the reasoning that the wife's claim is a debt of the community as a whole, would,

37 However, if the wife has only a claim against the estate of a deceased husband and not a property interest in the improvements, sbe may be prohibited from testifying in substantiation of this claim by CAL. Code Crv. Proc. $\S 1880(3)$. 
in effect, allow the husband to profit from his wrongful act, and is manifestly against the spirit of his statutory obligations. ${ }^{38}$ The only cases in which considerations have arisen that might be called similar are those that permit the wife's family allowance to be satisfied out of the entire community, including her portion of community property. ${ }^{39}$ This authority might be said to be against the contention that only the husband's estate and his portion of the community should be available to satisfy the wife's claim arising out of the husband's improvement of his separate realty with community funds. The family allowance cases should not present any real barrier to this contention, however, for different equities are involved there than in our example. The wife is afforded a family allowance pending disposition of her deceased husband's estate in order to ease any possible financial hardship she may encounter during this period. The considerations involved in our example are quite different, for we are not concerned with relieving a widow's financial hardship but with reimbursing the wife for the loss of funds that were once hers. Moreover, the family allowance is a statutory obligation, ${ }^{40}$ whereas, in the problem being considered here, if the husband has title to the improvements their construction with community funds was a wrongful act which itself is the foundation of the obligation. ${ }^{41}$

Such an obligation must, of course, be characterized either as a debt incurred on behalf of the community or as a debt of the husband separately. Still, assuming that the wife's claim is unsecured, the debt owed to her would seem to come under sections 168, 171, and 171b of the California Civil Code. Section 168 exempts the wife's earnings from "debts of the husband" and section 171 exempts the wife's separate property from such debts. Section $171 \mathrm{~b}$ exempts the separate property of the wife from community hypothecations. ${ }^{42}$ The case of Street $v$. Bertolone ${ }^{43}$ decided in 1924, held that debts of the husband were the same as debts of the community. Thus, regardless of whether the debt owed to the wife by the husband here is characterized as a community debt or a debt of the husband, the wife's statutory protection is limited to her earnings and separate property. Her argument that the claim ought to be satisfied solely out of the husband's separate property plus his one half of the community property could be countered with the argument that sections 168,171 , and $171 \mathrm{~b}$ of the Civil Code, as tied together by Street, furnish the exclusive protection of the wife from creditors of either her husband or of the community. The wife's obvious rebuttal to this argument would be that the legislature in enacting these sections of the code did not envision the possibility that the wife herself might be a creditor.

Finally, an argument can be made, regarding the husband's incurrence of an unsecured debt to the wife, that due to the addition of section $171 \mathrm{c}$ to the

38 See notes 22-25 supra and accompanying text.

39 Contrary to the widow's next contention ... the amount of her family allowance is a proper part of administration expenses chargeable to the community property .... The charge is a debt payable from the community estate. That allowance and the amount of the husband's debts must be deducted from the value of the community assets before the determmation as to the community property available for distribution may be made.

Estate of Resler, 43 Cal. 2d 726, 738, 278 P. 2d 1, 8 (1954).

40 See Cal. Prob. Code $\$ 680$.

41 See notes 22-25 supra and accompanying text.

42 See note 36 supra.

43193 Cal. 751, 226 Pac. 913 (1924). 
California Civil Code in 1951 the notion of community property ought to be modified. Depending on the interpretation of this section, the wife has, to a greater or lesser extent, control of her earnings. ${ }^{44}$ The argument here would be that when Street was decided the wife had no power to control any portion of the community property. Thus, it was only natural to conclude that since the husband was the sole manager of the community assets his debts were community debts. Today, however, since each party can obligate his or her own earnings, it may be reasonable to view the community as comprised of two portions of property, each of which is separate for the purpose of incurring debt. Accordingly, the party incurring the debt through exercise of control over his or her portion of community property ought to have to pay for it out of his or her separate property plus only his or her share of the community. In our example, the husband has misused his power of management and control and has thus incurred a debt to his wife. Applying the reasoning of this argument it is apparent that the husband would have to reimburse his wife out of his separate property plus his share of community property. ${ }^{45}$

\section{CONCLUSION}

With regard to title of improvements constructed with community funds upon the separate property of the husband, the cases may be summarized as follows: The Smith case, decided by the California Supreme Court in 1859, established the proposition that the husband ought not to be able to defeat the wife's interest in community property by using common funds to improve his children's separate property. It seems fair to conclude that the rationale of this case, based upon viewing improvements as but one form of community investment, would uphold community title to improvements built upon the husband's separate property. In support of such a result are Estate of Chandler and Long, decided by district courts of appeal in 1931 and 1948, respectively. Although the result seems sound, the accuracy of reasoning in these cases is doubtful, for both cases rely not upon Smith but upon a misinterpretation of Provost. Provost, the source of much confusion in this area, contains language which would support Smith, Estate of Chandler, and Long, but through reliance on Estate of Barreiro reaches a contrary result in refusing to acknowledge community title to any part of the improvements. The decision in Estate of Barreiro, it will be remembered, was based upon a misuse of reasoning in earlier cases, notably Shaw, which involved the use of community funds to construct improvements upon the wife's separate property. Additional confusion seems to have arisen

44 See note 2 supra regarding CaL. CIv. Code $\$ 171 \mathrm{c}$. Professor Harold Marsh is of the opinion that it is "fairly clear" that the wife would lose control over community property money earned by her if she were to use the money to purchase stocks, for stocks are not "money." He is unsure about control over a bank account in her name containing post-1951 earnings. If Professor Marsh is correct the addition of $\$ 171 \mathrm{c}$ gave the wife illusory control. See Calitornil Law Rerision Comm'n, Recommendation and Study Relating to Inter Vivos Mirital Property Richts in Property Acquired IVhile Domiciled Elsewhere, found in 3 Reports, Recomarmxdatioxs \& StUdies I-22-23 (1961).

45 In addition to modifying Street it would be necessary to hold inapplicable those cases which hold responsible the entire community, with the exception of the wife's earnings, for debts of the husband. See, e.g., Grolemund v. Cafferata, 17 Cal. 2d 679, 111 P.2d 641 (1941). 
out of cases which, while dealing with the husband's improvement of the wife's property, contain dicta broad enough to cover the husband's improvement of his own property. ${ }^{46}$

Essentially, then, we are faced with two lines of cases, each of which is unstable in terms of legal reasoning. If the improvements retain the character of the funds used to build them, as would seem to be the more reasonable result, title will rest with the community, in which the wife has a one half ownership interest. ${ }^{47}$ Conversely, if the improvements follow the title to the land, the extent of the wife's right to recover will depend upon whether the husband owes the duties of a trustee toward the wife in this situation, whether there are mortgagees and other creditors of the community, whether the wife's claim is secured or general, and whether satisfaction of the claim is to be made from community assets as a whole or is to be limited to the husband's separate property, plus his share of the community. As we have seen, all questions in this Pandora's box are open to speculation. They can best be avoided by deciding initially that the improvements built with community funds retain community title.

Laurence D. Kay

46 " $[I] \mathrm{t}$ is the general rule that improvements made during marriage on the separate property of either husband or wife, although with community funds, belong to the spouse owning the separate property." Dunn v. Mullan, 211 Cal. 583, 589, 296 Pac. 604, 607 (1931). See also Potter v. Smith, 48 Cal. App. 162, 191 Pac. 1023 (1920).

47 See note 1 supra. 